\title{
Faculty Use of Government Publications
}

The widespread differences which exist among libraries in their treatment of United States government publications suggest a need for additional study of the users of these materials. The findings in a survey of faculty use of government documents at Case Western Reserve University indicate how document users locate the materials they need, the users' familiarity with standard indexes to public documents, the age of government publications most frequently consulted, and other patterns of use.

T HE ACQUisition of U.S. government publications through the depository system places the recipient library in the favorable position of automatically and systematically receiving a significant number of these publications without any financial outlay for their purchase. At the same time the library is confronted with a most critical problem which, unresolved, can obviate or at least diminish any advantage the library may have as a depository. Simply stated, this is the problem of how to organize and service government publications in order to maximize their use and usefulness.

Several approaches to organizing and servicing documents collections are currently in general use by depository libraries. There is clearly widespread disagreement among libraries as to the relative merits of the various organizational schemes. Evidence of this was pre-

Mrs. McCaghy is history reference librarian, Bowling Green State University Library, Bowling Green, Ohio. Mr. Purcell is director, Graduate School of Library and Information Science, University of Tennessee, Knoxville. sented when the Documents Office conducted a survey of the existing depository libraries in 1947 and found that of the 471 libraries responding, only 174 used the Superintendent of Documents classification system, while the remainder used a number of other approaches or, as in the case of sixty-eight libraries, no organizational system whatsoever. ${ }^{1}$

The widespread lack of agreement among depository libraries as to the most appropriate way to treat government publications suggests that libraries base this decision on differing sets of priorities. These priorities are identified by Ellen Jackson as the arguments supporting one or another organizational scheme. ${ }^{2}$

The one factor which appears to be given only minimal consideration in determining an appropriate organizational scheme for government publications is the way in which people actually use public documents. A search of the literature from 1943 to the present reveals that no study showing use characteristics and needs related to government publications has ever been reported. Most of the literature is concerned with the acquisition, organization, or administra- 


\section{8 / College d Research Libraries • January 1972}

tion of documents, not with their use. The familiar questions of a separate vs. an integrated collection, complete vs. partial cataloging, and the Superintendent of Documents vs. some other classification scheme are all debated in the absence of any definite knowledge of the characteristics and behavior of the users. It is likely that in most cases the decision by new depository libraries as to which organizational scheme to use is based on an examination of this literature rather than on a study of the needs of the users of the library.

The authors of this paper studied patterns of faculty use of government publications at one depository library (Freiberger Library at Case Western Reserve University) in order to obtain data which could be considered in determining the future treatment of the documents collection. The study is reported here with the expectation that it might serve as a stimulus for other studies of the users of government publications and as a reference point to which such studies can be compared.

Data were gathered by means of a questionnaire designed to answer these questions:

1. What percentage of the faculty uses the documents collection?

2. How frequently is the collection used by faculty members?

3. How do users find the materials they want?

4. How satisfied are users with the assistance rendered by the library staff?

The questionnaire was distributed to one-third of the faculty members in the social sciences and the humanities, a sample which was drawn systematically from the faculty directory. Faculty members in the sciences were not included because Freiberger Library is the central social science and humanities library for the campus and has few holdings in the natural sciences. Of the 116 persons who received questionnaires,
103 , or 89 percent, completed and returned them.

\section{The SAMPLE}

Fifty-seven respondents ( 55 percent) were social science faculty members; thirty-nine ( 38 percent) were in the humanities; and seven ( 7 percent) in fine arts. The thirteen nonrespondents included four members of the law school, three from political science, two from the social sciences, and one each from education, psychology, speech, and history; or, eleven social science faculty members and two from the humanities.

The breakdown of the faculty rank of the respondents was as follows: thirteen ( 13 percent) were lecturers; eight ( 8 percent) instructors; twenty-nine ( 28 percent) assistant professors; twentynine (28 percent) associate professors; and twenty-four ( 23 percent) full professors. Among the thirteen nonrespondents there were one lecturer, four instructors, two assistant professors, one associate professor, and five full professors.

\section{The Results}

Table 1 shows that only one faculty respondent ( 1 percent of the total sample) uses the documents collection as often as two or three times a month. Fourteen persons (14 percent) use it once or twice a semester, and twentyfour ( 23 percent) once or twice a year. While the large majority (sixty-four persons or 62 percent) never use the collection at all, twenty-one respondents indicated that they use government publications in some other library and twenty-eight stated that they obtain their own personal copies of government publications.

The reasons for infrequent use of the documents collection are given in Table 2. [Respondents could check more than one response category, so the total will not equal 100 percent. Percentages are based on an $\mathrm{N}$ of 87 , the number of 
TABLE 1

Frequency of Use of Documents

DEPARTMENT

\begin{tabular}{lrr}
\hline \hline & $\mathrm{N}$ & $\%$ \\
\hline $2-3$ times/month & 1 & 1 \\
$1-2$ times/semester & 14 & 14 \\
$1-2$ times/year & 24 & 23 \\
Never $\quad \frac{64}{103}$ & $\frac{62}{100 \%}$ \\
$\quad$ Total & 103 & \\
\hline
\end{tabular}

TABLE 2

REASONS FOR INFREQUENT USE OF DOCUMENTS DEPaRTMENT

\begin{tabular}{lcc}
\hline \hline & $\mathrm{N}$ & $\%$ \\
\hline Unaware of its existence & 12 & 14 \\
Unfamiliar with its organization & 21 & 24 \\
Use government publications & 21 & 24 \\
$\quad$ in other libraries & 28 & 32 \\
Obtain own copies & 40 & 46 \\
Do not need government & 10 & 12 \\
publications & \\
Other & & \\
\hline
\end{tabular}

TABLE 3

Frequency of Use of Documents Dept.

COMPARED TO

Frequency of Use of Library in General

\begin{tabular}{lrr}
\hline \hline \multicolumn{1}{c}{ Frequency } & Documents & \multicolumn{1}{c}{ Library } \\
\hline $2-3$ times/month & $1(1 \%)$ & $68(66 \%)$ \\
$1-2$ times/semester & $14(14 \%)$ & $17(17 \%)$ \\
$1-2$ times/year & $24(23 \%)$ & $10(10 \%)$ \\
Never & $\frac{64}{103} \frac{(62 \%)}{(100 \%)}$ & $\frac{8}{103} \frac{(8 \%)}{(101 \%)}$ \\
$\quad$ Total &
\end{tabular}

persons who use the documents infrequently (once or twice a year) or not at all.] Of the eighty-seven persons who use the collection only once or twice a year or not at all, forty (46 percent) stated that they do not require government publications in their work. Twenty-one respondents ( 24 percent) use government publications at other libraries, and twenty-eight (32 percent) obtain their own personal copies.

Twelve persons (14 percent) are unaware of the existence of the government publications collection in the university library and twenty-one persons (24 percent) are unfamiliar with its organization. These categories suggest a need for more publicity about the availability and the organization of government documents in the library.

Comparing faculty use of the library in general with use of the documents collection in particular yields an interesting pattern (see Table 3 ). The frequencies of these two variables take opposite directions; that is, while the library in general is used by the majority of the faculty sample, such is not the case with the government documents department. Cross-tabulation (see Table 4) shows that while there is a weak relationship between the use of the library and the use of the documents collection, fully 57 percent of the frequent users of the library never use the documents collection.

Table 5 shows that among the thirtynine repondents who do use the documents collection, eleven persons ( 28 percent) require staff assistance more than 50 percent of the time; four (10 percent) require help from $25-50$ percent of the time; fourteen ( 36 percent) less than 25 percent of the time; and nine (23 percent) not at all. Eight of the thirty-nine users (21 percent) feel some reluctance, for the reasons given in Table 6 , in asking library staff members for assistance. However, most faculty users of the documents collection seem satisfied with the assistance rendered by the library staff. There were forty-four favorable responses and only ten unfavorable ones to the question asking about the staff's willingness and ability to provide assistance (see Table 7). (Respondents could check more than one response category. Percentages are based on an $\mathrm{N}$ of 39 , the number of users of the documents department.)

Users who do not generally require help in using the collection locate the publications they need in a variety of ways (see Table 8). (Respondents could check more than one response category. Percentages are based on an $\mathrm{N}$ of 23 , the number of users of the documents 
10 / College \& Research Libraries • January 1972

TABLE 4

Frequency of Use of Documents Dept, $\times$ Frequency of Use of Library

\begin{tabular}{|c|c|c|}
\hline Documents & \multicolumn{2}{|c|}{$2-3 /$ month } \\
\hline $\begin{array}{l}2-3 \text { times/month } \\
\text { 1-2 times/semester } \\
\text { 1-2 times/year } \\
\text { Never } \\
\quad \text { Total }\end{array}$ & \multicolumn{2}{|c|}{$\begin{array}{rr}1 & (2 \%) \\
13 & (19 \%) \\
15 & (22 \%) \\
\frac{39}{68} & \frac{(57 \%)}{(100 \%)}\end{array}$} \\
\hline \multicolumn{3}{|c|}{$\begin{array}{c}\text { Frequency of Documents Users NeEd for } \\
\text { Staff Assistance }\end{array}$} \\
\hline & $\mathrm{N}$ & $\%$ \\
\hline $\begin{array}{l}\text { More than } 50 \% \text { of time } \\
25-50 \% \text { of time } \\
\text { Less than } 25 \% \text { of time } \\
\text { Never } \\
\text { No Answer } \\
\quad \text { Total }\end{array}$ & $\begin{array}{r}11 \\
4 \\
14 \\
9 \\
\frac{1}{39}\end{array}$ & $\begin{array}{r}28 \\
10 \\
36 \\
23 \\
3 \\
100 \%\end{array}$ \\
\hline
\end{tabular}

TABLE 6

REASONS For Eight Users' ReLUCtance in Asking for Assistance

\begin{tabular}{lcc}
\hline \hline & N & $\%$ \\
\hline Question too elementary & 1 & $12 \%$ \\
Staff too busy & 4 & 50 \\
Staff unable to help & 1 & $12 \%$ \\
Other & $\frac{2}{8}$ & $\frac{25}{100 \%}$ \\
$\quad$ Total & &
\end{tabular}

TABLE 7

Users' Opinions of Library Staff

\begin{tabular}{lrr}
\hline \hline & N & $\%$ \\
\hline Willing to help & 27 & 69 \\
Successful in locating suitable & 13 & 33 \\
materials & 4 & 10 \\
Other (favorable) & 2 & 5 \\
Needed materials are not in & & \\
$\quad$ collection & 5 & 13 \\
Staff not very accommodating & 3 \\
Seldom locate suitable materials & 1 & 10 \\
Other (unfavorable) & 4 & 3 \\
No answer & 1 & \\
\hline
\end{tabular}

collection who require assistance less than 25 percent of the time.) The most frequently cited method is through citations in the literature of the users' particular fields of study. The library's pub- lic catalog, the Monthly Catalog of United States Government Publications and other special indexes, and browsing in the collection itself are the next most frequent means of locating relevant materials.

Among the thirty-nine users of the collection, nineteen persons can use the Superintendent of Documents classification system to find items on the shelves, and thirteen cannot. If it can be assumed that the seven persons who did not answer the question about the classification system are also unfamiliar with it, the users are almost equally divided between those who can (nineteen) and those who cannot (twenty) use the classification to locate a specific document. This lack of understanding of the scheme by which the documents collection is organized, combined with the percentage of users who require assistance (see Table 5), points to the need for a general reference staff which is well versed in all aspects of the documents collection.

The faculty's knowledge of the bibliographic tools providing access to government publications seems somewhat limited, though 58 percent of the persons who answered the question pertaining to catalogs and indexes are familiar with the Monthly Catalog of United States Government Publications, which is the major tool (Table 9). (Respondents could check more than one response category. Percentages are based on an $\mathrm{N}$ of 45 , the number of persons who answered the question.) Nearly 
half of them also know of the Price Lists, but familiarity with the other aids listed in the question is not extensive. It is interesting to compare this information with the ways in which users say they locate government publications. For example, although twenty-six persons indicate their familiarity with the Monthly Catalog, Table 8 shows that only ten actually use it to locate the publications they need.

The age of the government publica-

TABLE 8

How SELF-SUfFicient UsErs LOCATE DOCUMENTS

\begin{tabular}{lrr}
\hline \hline & N & $\%$ \\
\hline Public card catalog & 9 & 39 \\
Monthly Catalog & 10 & 44 \\
Special indexes and catalogs & 10 & 44 \\
Citations in the literature & 20 & 87 \\
Documents check-in file & 2 & 9 \\
Browsing in collection & 11 & 48 \\
No answer & 2 & 9 \\
\hline
\end{tabular}

TABLE 9

\begin{tabular}{|c|c|c|}
\hline \multicolumn{3}{|c|}{$\begin{array}{l}\text { Users' Familiarity Wrth INDEXes to } \\
\text { GoVERnMENT PUblications }\end{array}$} \\
\hline & $\mathrm{N}$ & $\%$ \\
\hline Monthly Catalog & 26 & 58 \\
\hline Price Lists & 20 & 44 \\
\hline Documents Catalog & 3 & 7 \\
\hline Tables and Index & 2 & 4 \\
\hline Ames & 3 & 7 \\
\hline Poore & 6 & 13 \\
\hline Checklist & 6 & 13 \\
\hline Government-wide Index & 11 & 24 \\
\hline Other special bibliographies & 11 & 24 \\
\hline None of above & 8 & 18 \\
\hline No answer & 12 & 27 \\
\hline
\end{tabular}

TABLE 10

Age of Government Publications Most OFTEN CONSUlted

\begin{tabular}{lrr}
\hline \hline & N & $\%$ \\
\hline Less than a year old & 7 & 14 \\
1-5 years old & 13 & 26 \\
6-10 years old & 2 & 4 \\
11-20 years old & 5 & 10 \\
Over 20 years old & 13 & 26 \\
First two categories above & 3 & 6 \\
First three categories above & 8 & 16 \\
No set pattern; age varies & \\
\hline
\end{tabular}

tions most often consulted suggests that most users could rather readily locate the materials they seek in the Monthly Catalog (see Table 10). (Percentages are based on an $\mathrm{N}$ of 51 , the number of persons who answered the question.) Thirty-three ( 65 percent) of the fifty-one persons who answered the question pertaining to the age of needed publications most frequently seek materials published within the last five years, and thirty-eight ( 75 percent) need materials from the last ten years. A basic knowledge of how the Monthly Catalog works should enable these users to find the items they want.

\section{SUMMARY}

The purpose of this study was to determine patterns of faculty use of U.S. government publications in a depository library whose documents are housed in a separate collection. The results are based on a small sample of respondents in one particular situation, and their representativeness can be ascertained only by replication of the study in other libraries. We present our findings in the hope that they will suggest directions which further research in this area might take.

In the library studied, the following patterns are evident from the data collected.

1. Fewer than half of the faculty respondents use the government documents collection in the university library. This does not mean, however, that overall faculty use of these materials is insubstantial; for 32 percent of the respondents indicated that they either use government publications located in some other library or obtain their own personal copies. This raises total use, regardless of location, to 65 percent of the total sample.

2. There is little correlation between faculty use of the library in general and of the documents collection in particular. Frequency of use of the docu- 
ments collection tends to be low, with the majority of users consulting materials there only once or twice a year.

3. Three-fourths of the respondents most often consult government publications which have appeared in the last ten years. The major approach to these publications is through citations in the literature of the faculty members' own fields of study. This method was cited twice as often as any other method of locating documents, including the use of the public card catalog. The fact that most users do not consult the card catalog raises important questions about the necessity of cataloging government publications in a depository library which maintains a separate documents department and utilizes the Superintendent of Documents classification system.

4. In spite of a limited familiarity with the bibliographic apparatus of government publications and the classifcation scheme by which they are organized, a majority of the faculty sample is relatively self-sufficient in using the documents collection. Even so, over onefourth of them usually need staff assistance. Those who require such help are generally satisfied with the service they receive.

5. Almost all writers in the area of government publications agree that these materials are too often neglected by those who could profit greatly from them. The single most important reason for this neglect is probably a simple lack of familiarity on the part not only of potential users but also of many librarians. One-fourth of the respondents in this study were either unaware of the existence of a separate documents department in the university library or unfamiliar with its organization and administration. Indeed, most of those who suggested methods of improving the documents collection addressed themselves to the question of increasing users' awareness of it. Among their specific comments were:

"Get out a brief statement on what is available, especially for student research."

"More advertising."

"Let-us teachers become more aware of the materials available, so that we eould pass on this information to -our students."

"This questionnaire informs me that there are such things. This may be one step in the right direction."

"Provide faculty and others with more information about the collection, its location, services, facilities, etc. Make sure competent personnel are in charge."

Any well-planned efforts to implement the above suggestions should result in making the university library's documents collection an even more effective and widely used resource for the entire campus community.

\section{REFERENCES}

1. R. B. Eastin, "Let's Use Public Documents!" Library Journal 74:1554-58 (1 Nov. 1948). A survey conducted in 1969 by Sally Bradshaw and Anne Blankenship of Weber State College Library in Ogden, Utah found that document depositories continue to be as diversified in their approaches to organizing documents collections as reported earlier by Eastin. The results of the Bradshaw-Blankenship survey were reported in a letter to depository libraries which participated in the study.

2. Ellen Jackson, A Manual for the Administration of the Federal Documents Collection in Libraries, Chicago: ALA, 1955 , p.22-32. 